\title{
HUNGARIAN CIVIL PROCEDURE PROVISIONS DURING THE STATE OF DANGER PERIOD
}

DOI: 10.24193/SUBBiur.65(2020).3.4

\section{László PRIBULA*}

\begin{abstract}
In March 2020, the Hungarian civil procedure faced an extraordinary challenge by the unpredictable but widely threatening Covid-19 epidemic, which necessitated the introduction of provisions as effective as possible to protect public health. The task was challenging because the public does not only expect the courts to settle the legal disputes righteously, but, based on a centurylong development in the history of law, the requirement of verbal and direct hearings has become of accentuated importance. The traditional model of civil cases centres around the public institution of hearings with the simultaneous presence of the judge, the parties, and their representatives, as well as other actors in the case. Simultaneously, the legislator accentuated the importance of concentrated and rapid case management, especially in the past few years. The extraordinary situation caused by the epidemic might have raised the complete close-down of courts. But, as there is no court proceeding without hearings, this solution could not have been acceptable by either the parties seeking to assert their rights or by court employees for reasons of human resources management, as the judgements of legal disputes would have been postponed for an undefined period. The interests of both the citizens seeking justice and the court employees could be fulfilled by a solution that created the conditions of uninterrupted jurisdiction and the avoidance of personal contacts to protect their health. After a necessary period of preparation resulting from the unexpected situation, this extremely difficult issue was solved by the Government Decree 74/2020 (from 31 of March), officially abbreviated as VEIR.,
\end{abstract}

* László PRIBula is University professor, head of Department of Civil Procedure a the University of Debrecen, Faculty of Law. 
which did not abrogate the generally effectual procedure rules, but merely adjusted them to the specificities of the crisis situation. The same happened to the civil procedure too. During the period of the state of danger, in contentious (and noncontentious) cases, depending on the date of bringing of the action, the regulations of either Act III of 1952 (the 1952 Civil Procedure Code, henceforth 1952 PP.), in force until the 31 of December 2017, or Act CXXX of 2016 (the current Civil Procedure Code, hereafter PP.), in power from the 1 of January 2018, were applicable, with the amendments included in the government decrees. This different regulation formed the special state of danger procedure law to mitigate the consequences of the epidemic.

Keywords: Hungarian 1952 Civil Procedure Code, Hungarian Civil Procedure Code, Hungarian civil procedure, Hungarian Government Decree 74/2020 


\section{Table of Contents}

I. The necessity of jurisdictional intervention as a result of the Covid-19 epidemic

II. Issuing and dissolving the extraordinary jurisdictional intermission....... 117

III. Provisional regulations of the procedural measures applicable during the period of state of danger............................................................................. 121

IV. Preparatory stage in the procedure law during the state of danger......... 123

V. The main hearing phase in the state of danger procedure law................ 126

VII. Procedural remedies in the state of danger procedure .......................... 130

VIII. Submitting documents in the state of danger procedure ........................ 131

IX. "Lexodus": the abolishment of the state of danger procedure ................ 133

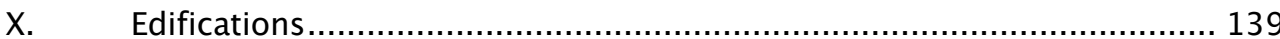

I. The necessity of jurisdictional intervention as a result of the Covid-19 epidemic

In March 2020 - besides several other aspects of life - Hungarian civil procedure faced an extraordinary challenge by the unpredictable but widely threatening Covid-19 epidemic, which necessitated the introduction of provisions as effective as possible to protect public health. The task was challenging because the public does not only expect the courts to settle legal disputes righteously but, based on a century-long development in the history of law, the requirements of verbal and direct hearings has become of accentuated importance. The traditional model of civil cases centres around the public institution of hearings with the simultaneous presence of the judge, the parties, and their representatives, as well as other actors in the case. Simultaneously, the legislator accentuated the importance of concentrated and rapid case management, especially in the past few years. 
The extraordinary situation caused by the epidemic might have raised the complete close-down of courts. However, as there is no court proceeding without hearings, this solution could not have been acceptable by either the parties seeking to assert their rights or by court employees for reasons of human resources management, as the judgements of legal disputes would have been postponed for an undefined period. The interests of both the citizens seeking justice and the court employees could be fulfilled by a solution that created the conditions of uninterrupted jurisdiction and the avoidance of personal contacts to protect their health. After a necessary period of preparation resulting from the unexpected situation, this extremely difficult issue was solved by the Government Decree 74/2020 (the 31 of March), officially abbreviated as VeIR., which did not abrogate the generally effectual procedure rules, but merely adjusted them to the specificities of the crisis situation. The same happened to the civil procedure too. During the period of the state of danger, in contentious (and noncontentious) cases, depending on the date of bringing of the action, the regulations of either Act III of 1952 (the 1952 Civil Procedure Code, henceforth 1952 PP.), in force until the 31 of December 2017, or Act CXXX of 2016 (the current Civil Procedure Code, hereafter PP.), in power from the 1 of January 2018, were applicable, with the amendments included in the government decrees. This different regulation formed the special state of danger procedure law to mitigate the consequences of the epidemic. ${ }^{1}$

\footnotetext{
${ }^{1}$ About another field of the period of danger, see: Judit Gál: A cégek müködését módosító, a veszélyhelyzettel összefüggő szabályok, Céghírnök 2020.4, 1-2. (Regulations during the state of danger modifying the operation of firms).
} 
II. Issuing and dissolving the extraordinary jurisdictional intermission

To understand the crucial provisions of the measures, it is essential to review the previous regulations. We have to highlight three significant dates. The first one was 3 pm, on the 11 of March 2020, when Govt Decree 40/2020 (the 11 of March) came into force, by which the Government issued the period of the state of danger, acting within its original legislative power laid down in Section 53 (1) of the Fundamental Law of Hungary. The second date was hour 0 on the 15 of March 2020, when the first article of Govt Decree 45/2020 (the 14 of March) issued the court vacation, and the third one was $3 \mathrm{pm}$ on the 31 of March 2020 when VEIR. came into force, and simultaneously the court vacation was dissolved. Court judging restarted to work uninterruptedly, in civil procedures according to the effective PP. and the 1952 PP., with the government decree's alterations.

As a response to the epidemic, the legislator decided to issue an extraordinary court vacation, which had not been introduced previously in the history of Hungarian law. After a fortnight, the legislator abrogated the court vacation, and at the same time, created an extraordinary procedure law. It is worth reviewing the reasons behind these regulations.

The state of danger procedure law could not be introduced simultaneously to the announcement of the period of the state of danger, as the definition of the conditions required the proper arrangement of legislation, given that such procedure rules had not been without precedent. However, the state of danger demanded instant intervention. After the announcement of the state of danger, the parties could not perform specific procedural actions. Still, there was no legislation about the consequences, as 
the duration and the legal effects of the court vacation were not arranged alongside the state of danger declared. (These were discussed in the instructions of the chairperson of the National Jurisdictional Authority (OBHE), being compulsory for the courts. ${ }^{2}$ ) As certain professional criticism highlighted, 3 the ordering of the extraordinary court vacation caused doubts because, without specific legal regulations, it could not be identified with the "normal" court vacation known in Hungarian civil procedure law. According to the Pr., each year, from the 15 of July to the 20 of August and from the 24 of December to the 1 of January, do not count in the time limit. This period is called court vacation, and the law associates the calculation of the time limits and the exceptions from the limits. ${ }^{4}$ The main point of calculating the time limit of the "normal" court vacation was that its terminal date was predictable, resulting from the regulations of the law. At the same time, the legislator could not foresee the end of the extraordinary court vacation. Only those legal effect could be associated with the extraordinary court vacation, which themselves would have been included in the regulations specifying the extraordinary court vacation; however, there were no such regulations.

Moreover, the legal effects of the court vacation did not include the special cases discussed out of turn, or in case both parties requested the dispensation of the time limit, as in these cases, there should have been hearings even in this period 5 - which was to be avoided in the state of danger. Consequently, through analogy, certain courts applied the legal

2 35.SZ/2020. (III. 15.) OBHE decision, 37/2020. (III. 17.) OBHE decision.

3 A peres eljárási határidők nem szünetelnek a rendkívüli ítélkezési szünetben sem, https://www.origo.hu/jog/20200331-tuller-ugyvedi-iroda-rendkivuli-itelkezesi-szunetperes-eljarasi-hataridok.html (date of downloading: 18.07.2020).

4 Pp., Section 148. (1).

5 Pp., Section 148. (3). 
effect of interrupting the procedure with regard to the state of danger, based on the concept that, according to the procedure code, the procedure is interrupted if the court is obstructed by an unavertable event, until the event terminates. ${ }^{6}$ Even though certain authors supported this solution in literature 7 , according to the grammatical interpretation of procedure laws, the interruption can be established if the complete action of the court becomes impossible physically (war, natural disaster). However, in the state of danger, the courts worked, even though in limited conditions. Consequently, the primary duty of the newly created state of danger procedure rules was to dissolve this uncertainty and to regulate the transitory period between the state of danger and the extraordinary court vacation and the effectuation of the government decree.

The new special procedure law had to be applied in all the procedures - including the civil procedures - under the force of the VEIR., thus in all the ongoing procedures on the day of the effectuation, and not only in the procedures started after the effectuation of the regulation. ${ }^{8}$ In order to proceed with the cases uninterruptedly, the naturally uncertain period had to be solved this way regarding the legal effects.

The final regulations of the VEIR. has determined important specifications regarding the transition. Consequently, if the deadline expired in civil contentious and noncontentious procedures during the period before the $15^{\text {th }}$ day following the effectuation of the extraordinary court vacation namely between the 15 of March 2020 and the 15 of April 2020 -, the time

\footnotetext{
${ }^{6}$ Pp., Section 119. (1) e).

7 Tímár Balázs: A koronavírus kihívásai és a jogtudomány: „Telik, de nem múlik” - a polgári bíróságok a veszélyhelyzet idején, https://jog.tk.mta.hu/blog/2020/o6/a-polgari-birosagoka-veszelyhelyzet-idejen (date of downloading: 18.07.2020) (Covid-19 challenges and law).

${ }^{8}$ Veir., Section 97 (1).
} 
limit elongated until the $30^{\text {th }}$ day following the effectuation of the VEIR., that is, until the 30 of April. So, VEIR. extenuated the uncertainties of the transitory period by elongating the time limits to the 30 of April 2020 that expired during the non-regulated period of the legal effects in the extraordinary period, and also the deadlines expiring after the grace period after the effectuation of the government decree. We also have to emphasise that it did not differentiate between the time limits specified by the law or by the court. 9

It was also necessary to create a provisional law in order to regulate the situation that several courts interrupted the court procedures regarding the instituting of the extraordinary court vacation, as they extensionally interpreted the civil procedure regulations. After the effectuation of the VEIR., the 31 of March 2020, the related interruption of the procedures terminated. We also need to highlight that in this case, only those interruptions halted, which were issued concerning the extraordinary court vacation. In contrast, the legal effects of halts given for other reasons proceeded according to the general procedure rules, since the government decree introduced a special halting cause, namely that in case the procedure required communication through a public notice, the procedure was halted until the termination of the reason for public notice or the termination of the period of the state of danger. ${ }^{10}$

It became necessary to determine a further transitory regulation of the procedures following the traditional procedure law in which the court had decided on the adjournment of the hearing, but it reserved the verdict but was not able to proceed with the hearing during the extraordinary court

\footnotetext{
9 Veir., Section 97(2).

${ }^{10}$ Veir., Section 27.
} 
vacation due to the epidemic situation. The transitory rule ordered the court to inform the parties about the written and explained judgement utilising postal delivery, not personal announcements. ${ }^{11}$

Beyond all these, the general standard regulation for civil procedures served the transitory period, which prescribed elongation during the state of danger ordered in Govt Decree 40/2020, from 3 pm on the 11 of March 2020 until the termination of the state of danger with regard to postal deliveries by means of establishing that the deliveries are effective, but if there should be a service complaint or an application for an excuse, the time limit of the service complaint and the application of service shall not include the period of the state of danger. ${ }^{12}$

\section{Provisional regulations of the procedural measures applicable during the period of state of danger}

From the 31 of March 2020, the coming into force of the VEIR., the extraordinary court vacation terminated, and the procedures continued according to the civil procedure code with the amendments justified by the epidemic situation. As opposed to the legal effects of the court vacation, a radically different solution was offered in the regulation according to which the state of danger does not influence the time limits, except when the decree does not regulate differently. ${ }^{13}$ As already mentioned among the closing regulations, another rule was the one about the extension of judicial

\footnotetext{
${ }^{11}$ Veir., Section 97 (4).

12 Veir., Section 1.

13 Veir., Section 21 (1).
} 
time limits expiring between the 15 of March and the 15 of April and the 30 of April; the previously presented extension of the time limit by the period of the state of danger for the submission of a service complaint regarding service of documents, or of an application for excuse; and another special rule was according to which, if the court orders a provisional measure before bringing an action upon a request to that effect, the time limit set by the court for bringing the action shall commence on the day following the end of the period of the state of danger. ${ }^{14}$ Another special regulation of time limits was according to which, during the period of a state of danger, with the exception to measures restricting personal freedom that can be performed in no other way, procedural acts that need to be performed at a location subjected to an epidemiological measure shall be performed after the epidemiological measures are lifted, with the proviso that the time limit for the performance of the procedural act shall recommence on the day following the lifting of the epidemiological measures. ${ }^{15}$

The primary measures of the VEIR. presented above were capable of the immediate resolving of the uncertainties due to the shortage of time of the then not thought over legislative intervention in respect to legal effects. Beyond this, however, the legislator was also expected to prepare for the epidemiological conditions to exclude the availability of personal client contacts for an unpredictably long period, even though the continuous action of the courts is an obvious public interest. The VEIR. attempted to prevent this conflict by justifiably effacing the principle of directness and by prioritising the judgements outside the hearing, and when the hearing is necessary, generalising hearing via means of digital tools.

\footnotetext{
14 Veir., Section 21 (6).

15 Veir., Section 22.
} 


\section{Preparatory stage in the procedure law during the state of danger}

The most important differences between the general and the state of danger procedure are naturally related to the hearings, as the to-be-avoided personal contacts would be most frequent here. The general organising principle was that in all the cases where the civil procedure law would also permit judging outside the hearings, it was compulsory in the state of danger procedure; but, when a hearing is unavoidable, it can happen only in a special way, which excludes the personal spatial presence of the actors of the procedure.

A particular challenge of the issuing of the state of danger procedure code was that from the 1 of January 2018, after fifty years, a new civil procedure code into force in Hungary. During the codification process of the new law, the legislator intended to create an up-to-date procedure code, which relies on the achievements of legal science and legal practices, and which suits the international practice and guarantees the effective assertion of substantive law. ${ }^{16}$ One of its most crucial conceptual modification was the introduction of the divided case structure instead of the single case structure by dividing the first-instance civil procedure into two stages, separated by an explicit court decision. The first one is the preparatory stage, which aims to specify the framework of the legal dispute, when the claimant has to present their statements of fact, and law and motions for evidence, and the respondent has to present their detailed response to the claim. Both parties have to present evidence supporting each statement of fact, and this stage is

${ }^{16}$ Govt Decree 1267/2013. (17 May) on the codification of the Pp. 
the exclusive opportunity to perform several procedure actions such as intervention on either side of the parties or changing the person of either party. The court closes the preparatory stage with an order against which a separate appeal may not be filed (case caesura). Then in the second, the main hearing phase begins the main evidentiary acts. In the preparatory stage, the hearing may be ignored; however, since the coming into force of the civil procedure code, this event has only happened rarely. In case there is a hearing held, the presence of the parties is required. In the main hearing phase, the court cannot ignore holding a hearing, the judgement can be delivered only based on hearing, even though the parties' participation is not a requirement.

As a result of the requirement of hearing, the most important conceptual differences of the state of danger procedure law can be introduced in the first-instance procedure, as the majority of the procedure acts necessary for the judgement of the legal dispute take place in this phase, the statements, presentations which require personal action, have primary relevance here.

First of all, VEIR. attempted to preserve health by expressing that the firstinstance court consists of one professional judge, even in those exceptional cases when the provision of the law ordered a council of judges, such as in labour cases only one judge acts, without assessors. ${ }^{17}$

The VEIR. kept the divided case structure in the cases initiated subjected to the Civil Procedure Code entering into force on the 1 of January 2018. However, while in the general procedure law, the preparatory phase permits three ways for the court to prepare a case, and the court may also close the preparation outside the hearing, but then, at the request of either

17 Veir., Section 23. 
party, it is required to hold a hearing. On the other hand, the court may order a further written preparatory stage, but then it is required to impose a hearing by ordering a reply document. Finally, the court may set a hearing without a further written preparatory stage. However, in the state of danger procedure, it was impossible to hold a hearing in the preparatory phase, even the parties could not require the hearing.

The exceptional rule of the PP. became a mandatory rule. In the state of danger procedure, the court could close the preparatory stage also after they communicated the regular statement of claim with the respondent, and the respondent submitted the written counter-claim (or a written statement of defence in writing), and the court stated that the frameworks of the legal dispute were clarified based on the counter-claim and the statement of defence. If the court did not find it sufficient, the court could notify the parties to submit further statements in writing, the number of which the VEIR. does not limit, and thus the parties could be notified again and again to make statements as long the court found the collection of statements reasonable to close the preparatory stage reassuringly. Before closing the preparatory phase, the court was obliged to notify the parties in writing and ensure the opportunity for them to submit further written statements. Thereafter, the court informed the parties about the closing of the preparatory stage. It was an essential rule that these were the normative regulations also for the cases involving personal status, and thus, there was no hearing in these cases in the preparatory stage. It usually happens that in cases involving personal status, but also in other cases, it may be necessary to hear the party or their legal representative in the preparatory stage. It was impossible to hold a hearing even in these 
cases. In such a case, the court could acquire the statements in writing or via an electronic tool, and the fact had to be registered in the minutes. ${ }^{18}$

\section{The main hearing phase in the state of danger procedure law}

The main hearing phase rules following the preparatory phase were utterly different in the state of danger procedure law. In this phase of the first instance process, such actions are performed as the taking of evidence, which would require the procedural actions at a hearing. But the avoidance of personal contacts had to be solved here to protect the participants' health. Consequently, VEIR. introduced a unique procedure that prevailed in a special order. We have to emphasise that in the cases initiated under the scope of the 1952 Pp., there was no divided case structure, so the provisions of the decree were to be regarded as normative in all the cases initiated under the scope of the 1952 PP. According to the special regulations, the main hearing had to be possibly held via an electronic communication network or another tool capable of transmitting picture and sound. The hearing held by this method did not traditionally take place in the courtroom open to the public, with the simultaneous presence of the court, the parties and other actors of the case, but via an electronic connection. In many instances, however, the conditions of all the actors of the case to be present via an electronic communication network or other tools capable of transmitting picture and sound were not given. In these cases, according to the decree, instead of holding the hearing, the court could receive the

${ }^{18}$ Veir., Section 21 (2). 
statements that had to be taken in writing or via means of an electronic tool that was capable of identification, and the fact could be recorded. There could also be cases when the court could not receive the statements to be taken even by these means. In these cases, the court could act upon the methods included in the VEIR.; and if the court conducted these procedural actions, or there were no such procedural actions to de conducted, the court could state in a provisional measure the date of the occurrence of the obstacle, which excluded the conduct of the action. It did not close the procedure, but the time limit set by the court for bringing the action commenced on the day the obstacle from the procedural step requiring personal action but not implementable without the application of identifiable electronic tool, or in writing, or on a hearing via an electronic device averted (or on the day following the end of the period of the state of danger). After the obstacle averted, the cancelled procedural actions have to be implemented. The court has to inform about the legal effects in the provisions about the obstacle in the proper way. ${ }^{19}$

As the law ordered about the "possible" holding of the hearing via means of electronic communication network or other electronic appliance capable of transmitting picture and sound simultaneously, the law enforcer necessarily had to interpret the possibility practically. Consequently, the Civil College of the Curia, the supreme judicial body responsible for the unity of legal practice, announced in its directive opinion that during the implementation of the VEIR. in civil cases hearings via other electronic tools capable of transmitting picture and sound simultaneously (so-called ehearings) can only be held if the necessary technical requirements are available for all the persons to be summoned to the hearing, not including

19 Veir., Section 21 (3), (4). 
the members of the court. The court has to investigate the requirements officially, and if all the persons involved meet them, the e-hearing can be appointed. The requirements for the presence on the hearing of the parties, the persons involved, and other persons are that, for the court's summons, they previously announce their e-mail addresses, and they have internet access and a tool capable of transmitting picture and sound simultaneously. The holding of an e-hearing can be omitted if the necessary technical conditions are not given or if, at the hearing, a procedural action has to be implemented that requires personal attendance unassured at an e-hearing. ${ }^{20}$

Among the procedural regulations of the state of danger procedure law, the most difficult approach for law enforcers was that when omitting ehearing, the special rules facilitated the implementation of procedural actions via written communication or electronic tool capable of identification, which actions would have taken place at a hearing, in the guaranteed framework of direct orality and publicity. That is why an interpretation emerged in judicial practice, which originated in the fact that written witness evidence is impossible because it requires the parties, the legal representatives, the witnesses, and the court to be present simultaneous personal presence for guarantee reasons, and thus the requirement of questioning the witness cannot be carried out without the simultaneous spatial presence of the parties. This approach emphasised that the written witness evidence as such cannot fulfil the expectable guarantee rules because it cannot be stated whether the evidence was really written by the witness or was not under influence, so the evidence does not have

20 Opinion 2/2020. (30 April) of the Civil College of the Curia on the requirements of hearings held via electronic tools capable of transmitting picture and sound simultaneously during the period of state of danger. 
probative value, and no judgement can be based on it. As opposed to this approach, however, the majority opinion can be supported, also advocated by later legislation, according to which it can be unambiguously deduced from the aims and the circumstances of the regulations of the "VEIR." by the Pr. that in the state of danger procedure law the evidence of the witness could be provided in writing or via means of an electronic tool facilitating identification in the absence of the conditions of a main hearing. In the state of danger procedure law, during the witness evidence in writing or via another capable tool, the procedural rights were assured for the parties and were not injured, only they could not be guaranteed spatially and temporarily simultaneously, but in other form and by procedural actions realised in separation from each other. As far as it was possible, the VEIR. attempted to assure the protection of life and health, and at the same time, the continuous operation of the courts, but the regulation was triggered by the presence of the state of danger. The special procedural rules often require a unique approach, and in this situation, the implementation of the regulations of the PP. is not entirely possible in the regular procedural order, only with the governing regulations of the state of danger order. As a consequence of the judge's freedom of procedure conduct, it could not be excluded that, based on the deliberation of all the circumstances of the legal dispute, the acting judge could decide in exceptional cases that the written witness evidence could not be expected to be considered, and decided to announce the procedure as indisposed. 


\section{Procedural remedies in the state of danger procedure}

In appeal and review procedures, the governing order was judgement without hearing. While according to the general procedure law, in both the appeal and the review procedures - excluding the narrow range of exceptions specified by the PP. such as cases of mandatory expiry - at the request of the parties, the court must hold a hearing. The parties could not, for any reason, request a hearing in the state-of-order procedure law. The VEIR. changed the scope of the regulations of procedural remedy by not allowing the parties to submit a request for a hearing. By its interpretation, the judiciary expanded this regulation to the circle of cases when the parties had requested the hearing before the period of the state of danger, but the hearing had not yet been appointed. ${ }^{21}$ In some instances, it could happen that the parties had requested the hearing in appeal or review procedures, and the court appointed the hearing after the coming into force of the VEIR. In these cases, the procedural remedy court could decide on the judgement outside a hearing, about which it was required to inform the parties. Exclusively, in this case, the decree offered the opportunity that at a joint request by the parties filed within 15 days after the court notifies the parties of adjudicating the case outside the hearing, but only under the provisions in force concerning the special regulations of the main hearing. ${ }^{22}$

${ }^{21}$ Opinion 2/2020. (30 April) of the Civil College of the Curia on the requirements of hearings held via electronic tools capable of transmitting picture and sound simultaneously during the period of state of danger.

22 Veir., Section 29 (1)-(3). 


\section{Submitting documents in the state of danger procedure}

The VEIR. included several different provisions in connection with the submitting of documents, consistent with the requirements of the state of danger, and at the same time taking into account the procedural rights of the parties. During the state of danger, the administration offices of the court were not open for the clients so that the documents could be placed in the close cabinet at the entrance of the court building. Parties acting without legal representative were not to conform to the form constraint specified by the general procedure law (which was introduced in the new civil procedure code to strengthen professional case conduct but has resulted in several practical difficulties to apply since it came into force). In cases started under the scope of the PP. outside the special period, the party acting without a legal representative is obliged to submit the letter of claim, the document containing the statement of claim, the reply document, the statement of counter-claim, and the set-off document on the special forms. But in the state of danger procedure, the party acting without a legal representative could submit these statements only in writing - these statements could not be made orally in front of the court -, but they could even submit these either on a printed form of without a printed form. ${ }^{23}$ The state of danger procedure also imposed a necessary provision mandatory for the court concerning the party acting without a legal representative about the statement of claim submitted without a printed form. In the case, if the statement of claim submitted by the party acting without legal representative did not include the obligatory elements of content or form, the court had to indicate all the deficiencies of the statement of claim in the

23 Veir., Section 24. 
request summoning for the remedy of deficiencies, and the court must provide full detailed information regarding the remedy of deficiencies, having regard to the lack of legal knowledge of the party as appropriate. Rejection was possible only in the case if this was unsuccessful. The statement of claim could not be rejected regarding deficiencies, the remedy of which the court had not given detailed information conforming to the legal inexperience of the party acting without a legal representative. ${ }^{24}$

Further crucial provisions endeavoured to close the case quickly by avoiding the hearing. So, if the parties wished to make a settlement, the court could approve of it outside hearing with an order after the submitting of the written statement of the parties in the preparatory or the main hearing phase, in the proper ways specialised by the VEIR. In these cases, the court notified the parties about the order approving the settlement; the order was appealable regarding the term of the execution of the settlement. ${ }^{25}$ What further simplified the procedures was that the VEIR. made it possible to close the ongoing procedures started and postponed before it is coming into force with a judgement outside hearing if the implementation of further procedural action during the state of danger was unnecessary or which the court had implemented according to the provisions of the decree. In these cases, the court had to notify the parties about closing the hearing and provide the opportunity to make further written statements, and then could they close the procedure and notify the parties by delivery about the judgement outside hearing. ${ }^{26}$

\footnotetext{
24 Veir., Section 25.

25 Veir., Section 28 (3).

${ }^{26}$ Veir., Section 28 (1).
} 
IX. "Lexodus": the abolishment of the state of danger procedure

The abolishment of the extraordinary state of danger procedure law and the restitution of the traditional procedure also meant special legislative tasks, just like its introduction and maintenance. It was impossible to restore the general procedure regulations without provisional rules, given that the legal effects of several already started but not yet closed cases had to be customised to suit the specificities of the state of danger procedure. The legislator solved this transition in two steps: first, with Govt. Decree 229/2020. (the 25 of March) (Henceforth: Módr.) partially restored the regulations of the "traditional" order of the PP. from the 1 of June 2020. At the same time, the state of danger ordered by Govt. Decree 40/2020. (the 11 of March) still existed then, and specific provisions of the state of danger procedure were still in force, and beyond that, transitory rules assured the prevalence of the legal effects of specific procedural actions implemented until the 1 of June 2020.

From the 1 of June 2020, the court office hours specified for clients acting without a legal representative to have their submitted requests registered in the minute, as well as the opening hours at the court office for personal contacts, and submissions could be presented by person. The opportunity of personal contacts terminated the possibility of submitting written statements and of submitting statements via means of electronic tools capable of identification; the preparatory hearing, the main hearing (including the hearing in cases under the scope of the 1952 Pp.), and the

\section{3}


appeal and review hearing were to be appointed according to the general rules again. ${ }^{27}$

Concerning the appointment of hearings, however, the Módr. has introduced transitional regulations. In the case, if on the 1 of June 2020 the procedure was still in the preparatory stage, then, if between the 31 of March 2020 and the 1 of June 2020 the court had received the necessary statements - which specified the framework of the legal dispute - for the closing of the preparatory stage outside hearing, the court closed the preparatory stage by omitting the preparatory hearing. In this case, if the court had started the preparatory stage between the 31 of March 2020 and the 1 of June 2020, but by the 1 of June 2020, the parties had not submitted their statements specifying the framework of the legal dispute, the court could choose between appointing the preparatory hearing or continuing the preparatory stage by omitting the preparatory hearing. In the latter case, however, permitting the parties to request a preparatory hearing. ${ }^{28}$ In the case if, on the 1 of June 2020 the procedure was already in the main hearing phase (or the case belonged under the scope of the 1952 PP.), if the court had already notified the parties of closing the hearing in the period between the 31 of March 2020 and the 1 of June 2020, and the parties made their statements by the notification, or had not made their statements during the given term - the court made its judgement outside the hearing; if in the period between the 31 of March 2020 and the 1 of June 2020, the court had appointed the hearing via the means of electronic communication network or other electronic tool capable of transmitting picture and sound simultaneously (or the hearing in the cases belonging under the scope of the

\footnotetext{
${ }^{27}$ Módr. Sections 2 and 10.

${ }^{28}$ Módr. Section 2.
} 
1952 PP.) - the court was obliged to specify the place of the hearing (primarily the official court room of the court building, or for important reasons, as exception, another site), and to notify the summoned persons of it; and in the case in the period between the 31 of March 2020 and the 1 of June 2020, the court had not appointed the main hearing (or the hearing in the cases falling under the scope of the 1952 PP.) - also including the cases if the court stated the obstacle of the procedure - the court continued the procedure by appointing the hearing according to the general procedure rules. ${ }^{29}$ In the case if on the 1 of June 2020, the procedure was in the amendment phase, in the court had notified the parties on the judgement outside of hearing in the period between the 31 of March 2020 and the 1 of June 2020, the court acted outside of hearing; and if the court had not notified the parties of the judgement outside of hearing in the period between the 31 of March 2020 and the 1 of June 2020, the hearing or the judgement outside of hearing carried on according to the general procedural rules. ${ }^{30}$

Accordingly, from the 1 of June 2020, there are no more e-hearings, but the hearing can be held by this means if the epidemiological measures justify it. Beyond this, the court may exclude the public from the hearing because of epidemiological efforts, even if it can assure the observability of the epidemiological measures in the court hearing room.

It was an essential change that from the 1 of June 2020, there was no opportunity to consent settlement outside of hearing - but in case if in the period between the 31 of March 2020 and the 1 of June 2020, according to the regulations of the VEIR., the court had already heard the parties on the

\footnotetext{
29 Módr. Section 4.

${ }^{30}$ Módr. Section 5.
} 
issue of the settlement, and could consent to the settlement of the case outside of the hearing. From this time on, the provision was not in force any more, which ordered that in contentious cases, the procedure shall be stayed in limitless number by the request of all parties. From the 1 of June 2020, there is no opportunity for a sole judge to act in first-instance labour cases, where lay judges shall act as ordered by the law. ${ }^{31}$

Several state of danger provision are still in force after the 1 of June 2020. It was still relevant that concerning the service of documents during the state of danger, the state of danger does not count in the time limit of submitting an application for excuse about delivery and omission. The regulation is still in force according to which during the period of the state of danger, no procedural action shall be conducted, if it should be implemented at a place under the scope of the epidemiological measure, except for those actions involving the restraint of personal freedom, which cannot be implemented. Such an action shall be conducted after lifting the epidemiological measure with the restriction that the time limit regarding the procedural action restarts on the day after the lifting of the epidemiological measure. It is essential that the provision is still in force according to which during the state of danger, the statement of claim, the document of claim, the statement of counter-claim, the set-off document, and the written statement of defence can also be filed in writing by the party acting without a legal representative without the application of the form prescribed in the law. The law is also still in force that in the case if the statement of claim submitted by the party acting without a legal representative does not include the obligatory content elements or formal requirements, the court shall present all the deficiencies of the statement of claim in the notice to remedy deficiencies, and the court

${ }^{31}$ Módr. Sections 2, 3, and 4. 
shall give detailed information conforming to the legal inexperience of the party, and only after its unsuccessfulness shall the court reject the statement of claim. The rule did not change regarding the fact that if the court informs the parties by public notice during the state of danger, the procedure interrupts until the reason for public notice terminates, or the state of danger terminates. $3^{2}$

In the second step, the Govt Decree 282/2020 (the 17 of June), based on the authorisation of Act LVII of 2020, lifted the state of danger, in connection to it, it became necessary to specify the transitory regulations to terminate the further special rules of the state of danger procedure law, which was realised by Act LVIII of 2020 (henceforth Transitory Law) about transitory rules and epidemiological preparedness concerning the termination of the state of danger.

The Transitory Law created rules to guarantee the abolishment of the special procedural provisions during the state of danger. So, if according to the regulations in force during the state of danger, a public notice should have been applied in the procedure, and as a result, the court stated the interruption of the case, then the interruption - unless the reason of the public notice ceased to be earlier - terminated at all events by the termination of the state of danger, and the court was obliged ex officio to continue the procedure 33 If the court ordered provisional measures before starting the case - at a request-the time limit for the starting of the matter determined by the court started on the day following the termination of the state of danger. 34

\footnotetext{
32 the Módr. did not affect the relating regulations of the Veir.

33 Provisional Law, Section 141.

34 Provisional Law, Section 137 (3).
} 
Beyond all this, the Módr. properly managed the transitory provisions of the preparatory and the main hearing phases and the procedural remedy proceeding regarding the appointment of the hearing. At the same time, the relatively short period between the coming into force of the Módr. and the termination of the state of danger necessitated the specialisation of the rules of the transition to the regular procedure in the cases if the transitory provisions had not taken place until the termination of the state of danger (which were essentially similar to the provisions of the Módr.). 35

However, - similarly to the provisions of the Módr. - several provisions related to the state of danger procedure remained in force partially or wholly - after the termination of the state of danger, consequently not only the prohibition to calculate the time limit of servicing excuse and the request for excuse neglecting the time span of the state of danger ${ }^{36}$ remained in force, as well as the prohibition to conduct procedural action at a place under the scope of the epidemiological measure, but beyond these, the law kept in force those regulations not directly related to the state of danger, according to which the party acting without a legal representative can submit the statement of claim, the statement of opposition, the letter of counter-claim, the statement of defence, and the set-off document, and not exclusively in writing, but also orally presented, even on a complaint day, without applying the printed form ordered by the law. ${ }^{37}$ Furthermore, even after the termination of the state of danger, the rule remained in force that in the case if the statement of claim submitted by the party acting without a

\footnotetext{
35 Provisional Law, Sections 137 (1)-(2), 142 (1)-(3), and 143 (1)-(3).

${ }^{36}$ Provisional Law, Section 93.

37 Provisional Law, Section 140 (1).
} 
legal representative did not contain the obligatory content elements or formal requirements, then, in its notice to remedy deficiencies, the court shall indicate all the deficiencies of the statement of claim in detail conforming to the lack of legal knowledge of the party, and only after its unsuccessfulness shall the court reject the statement of claim. The latter provisions unambiguously referred to the intentions of the legislator to preserve specific procedural rules to become generally prevailing, which had been tried and tested in the state of danger procedure law but had been created as extraordinary. ${ }^{3}$

\section{Edifications}

The regulations of the state of danger procedure law managed to achieve the direct aims, which the legislator intended to realise by the extraordinary procedural provisions: to exclude personal contacts while the courts continue to work, and the parties could practice their procedural rights fully, even though in particular ways. Legislative solutions involving the more extensive use of electronic tools and simplifying the procedures may serve as useful lessons for the future. It can turn out in the near future, to what extent legislation and law application can take advantage of the forced but necessary innovations in the traditional procedure. There are also signs: on the 9 of June 2020, a new act came into force regulating the accelerated case started to recompense damage caused by offence and tort, which, among others, attempted to achieve the efficiency of the procedure by judging outside hearing in the case if it is unnecessary to take evidence apart from documentary evidence, in other cases the hearings shall be held via the

$3^{8}$ Provisional Law, Section 140 (2). 
means of electronic communication network or other electronic tools capable of transmitting picture and sound: for this purpose, the claimant shall state in the statement of claim, and the defendant shall state in the written counter-claim, which kind of electronic tool capable of transmitting picture and sound, or an internet network the submitting party and their legal representative wish to use to keep contact with the court, by not appearing in person and by enabling identification, and also appointing the electronic availability facilitating the communication. ${ }^{39}$ The changing approach of directness may bring forth the renewal of procedure law, which may result in the more concentrated case conduct through the experiences of the necessarily introduced state of danger procedure law.

39 Act LXX of 2020, Sections 7 (2) and 11 (1)-(2). 